Indonesian Journal of Islamic Communication, Vol. 2, No. 1, Juli 2019: 72-89

\title{
PENERAPAN FUNGSI KELUARGA ERA CYBERSPACE DI KELURAHAN CATUR RUNGGAL SLEMAN YOGYAKARTA (PENDEKATAN KOMUNIKASI INTERPERSONAL)
}

\author{
Mike Meiranti \\ Fakultas Dakwah Dan Ilmu Komunikasi \\ UIN Sunan Kalijaga Yoyakarta
}

Diunggah 02 Mei / Direvisi 20 Juni / Diterima 26 Juli 2019

\begin{abstract}
Abstrac: Family is a relationship that is bound by marriage ropes where in fostering the family of husband and wife have the best hope for the continuity of the family. Basically the formation of a family is to carry out family functions in order to form a happy happy family, family functions such as religion, education, social, protection, intuition, economy, recreation, and bilological. However, in the development of the world of cyberspace family functions have begun to shift its application, this is due to the development of cyberspace which has formed a new pattern of thinking, lifestyle and orientation in a family so that families who cannot control the development of cyberspace will be vulnerable to internal conflicts and will adversely affect developing children if parents tend to be busy with their activities in cyberspace compared to the real world. Seeing this reality, the most effective thing for the application of family functions to work well is by interpersonal communication between each family member. Where culture of communication becomes a powerful weapon in carrying out the roles and functions in the household. In this paper researchers will use qualitative methods that are descriptive
\end{abstract}

Keywords; Family, Interpersonal Communication, Methodology

Korespondensi: Mike Meiranti

Fakultas Dakwah Dan Ilmu Komunikasi UIN Sunan Kalijaga Yoyakarta

Meirantimike@gmail.com 


\section{A. PENDAHULUAN}

Keluarga merupakan unit terkecil masyarakat yang dapat merumuskan aspekaspek sosial yang diberlakukan dalam masyarakat dimana keluarga terdiri dari beberapa unsur yaitu ayah, ibu dan anak. Dalam keluarga unsur tersebut memiliki peran yang beragam dimana ayah menjadi kepala keluarga yang berperan mencari nafkah dan melindungi istri dan anaknya, sedangkan ibu memiliki peran untuk merawat suami dan anaknya serta bertanggung jawab menlindungi harta suaminya, kemudian anak memiliki peran sebagai pengikat hubungan antara ayah dan ibu.

Keluarga memiliki peran yang sangat vital dalam keberlangsungan hidup masyarakat, dimana di dalam keluargalah lahir generasi-generasi baru penerus peradaban serta pembentukan watak dan karakter pun di bentuk dalam ruang lingkup keluarga. Ketika generasi yang di lahirkan didik dan di ajarkan dengan cara yang baik maka akan terciptalah populasi masyarakat yang baik pula dan begitu juga sebaliknya ketika generasi yang dilahirkan tidak di bentuk dengan cara yang baik maka akan lahir populasi yang tidak baik dan meresahkan kehidupan sosial masyarakat.

Setiap keluarga pasti menginginkan terbentuknya rumah tangga yang baik sakinah, mawadah, warahmah, dan dalam proses mencapai keinginan tersebut segala unsur keluarga harus menjalankan fungsi keluarga dengan baik, dimana terdapat 8 fungsi keluarga didalamnya yaitu fungsi agama, fungsi sosial budaya, fungsi cinta kasih, fungsi melindungi, fungsi reproduksi, fungsi sosialisasi dan pendidikan, fungsi ekonomi, fungsi pembinaan lingkungan ${ }^{1}$.

Agar penerapan fungsi keluarga tersebut dapat berjalan dengan baik maka harus di landasi dengan komunikasi yang baik antara unsur-unsur yang ada, dimana komunikasi Sama seperti jantung yang memompa darah ke seantero tubuh, komunikasi memompa kehidupan ke seantero keluarga. Jadi, seberapa sehatnya keluarga dapat diukur dari berapa sehatnya komunikasi dalam keluarga itu. Untuk itu kita perlu berkomunikasi guna memberi dorongan kepada unsur-unsur keluarga agar dapat menjalankan 8 fungsi keluarga dengan baik.

Namun penerapan komunikasi dalam keluarga saat ini tidak sesederhana itu karna ada beberapa hambatan yang memicu jarak antara keluarga yang disebabkan

1Delapan Fungsi Dalam Keluarga Ini Mengacu Pada Peraturan Pemerintah No 21 Tahun 1994 
oleh perkembangan teknologi dan informasi terutama di era revolusi cyberspace. melihat realitas yang ada, dampak revolusi cyberspace dalam keluarga sangat signifikan keberadaannya, ketika komunikasi antara ayah, ibu dan anak seakan di belenggu oleh jarak. Padahal faktanya posisi ayah, ibu dan anak sangat dekat dalam sebuah ruang tertutup (rumah) akan tetapi dihadang tembok raksasa yaitu berupa gadget yang menawarkan kehidupan virtual yang lebih menarik. hal ini otomatis membuat intensitas komunikasi antar keluarga terhambat dan penerapan 8 fungsi keluarga akan terganggu. Namun bukan hanya itu prilaku seperti ini akan rentan memicu konflik karna tidak ada ruang komunikasi dan mediasi dalam penyelesaian masalah dalam keluarga.

Dari beberapa sumber yang dapat ternyata dampak cyberspace dalam keluarga tidak hanya menganggu proses komunikasi efektif antara anggota keluarga, akan tetapi memberikan dampak buruk terhadap pola asuh anak. Akan tetapi dalam penelitian ini penulis fokus pada pembahasan ranah proses komunikasi karna vitalitas dalam pola asuh adalah komunikasi. Melihat realitas yang ada penulis ingin meneliti dampak cyberspace dalam keberlangsungan fungsi keluarga dan penulis ingin memberikan solusi berdasarkan contoh yang ada untuk mengatasi dampak cyberspace dalam keluarga menggunakan komunikasi interpersonal, dimana komunikasi interpersonal merupakan sebuah bentuk komunikasi yang efektif guna memperkuat hubungan antara keluarga.

\section{B. PEMBAHASAN}

\section{Kerangka Teori}

\section{a. Cyberspace}

Dengan semakin berkembangnya teknologi komputer dan seiring dengan perkembangan teknologi telekomunikasi . berbagai komputer dapat dihubungkan untuk membnetuk jaringan yaitu internet. secara khusus perkembangan teknologi komputer dan internet memberikan implikasiimplikasi yang signifikan terhadap pengaturan atau pembentukan regulasi dalam ruang cyber salah satunya cyberspace ${ }^{2}$

\footnotetext{
2 Josua Sitompul, Cyberspace, Cybercrime, Cyberlow, (Jakarta: PT Tatanusa, 2012), 33-34
} 
Cyberspace merupakan dunia virtual yang terbentuk dari hasil penyatuan antara manusia dan teknologi, yaitu dari perkembangan teknologi informasi dan komunikasi (information and communication technology-ICT). Kehadiran cyberspace merupakan awal dimulainya peradaban informasi dimana informasi dapat diperoleh dan dikirimkan serta disebarkan dengan mudah kebnayak orang dalam waktu yang cepat dan setiap orang juga dapat mengirim dan menerima informasi secara elektronik dalam berbagai bentuk dalam jumlah yang sangat banyak ${ }^{3}$ Munculnya cyberspace yang didasari munculnya jaringan internet sebagai ruang publik baru kelas menengah indonesia, hal tersebut dapat dilihat dari intensitas pengguna media sosail sebagai alat utama media baru di indonesia. Adapun media baru di indonesia yang menjadi trandsetter di kalangan kelas menengah indonesia seperti whatsapp WA, facebook, twitter, instagram yang dapat di akses melalui smartphone. Masyarakat indonesia megakses media sosial melalui smartphone mencapai 85 persen. ${ }^{4}$

Menurut john perry barlow berdasarkan definisi yang sekarnag cyberspace adalah ruang yang muncul ketika anda sedang menelpon. Cyberspaceadalah ruang informasi akan tetapi ia adalah ruang komunikasi yang lebih interaktif yang diciptakan oleh media yang begitu penuh sehingga disana terdapat kehadiran orang lain atau bisa juga cyberspace dikatakan sebagai ruang yang muncul ketika seseorang membaca buku yang membedakan cyberspace dengan membaca buku adalah adanya interaski lansgung antara pengarnag buku yang di baca. Atau menurut william gebson (1984) cyberspace adalah dunia halusinasi yang berupa grafis yang diolah manusia 5

\footnotetext{
${ }^{3}$ Ibid, 26

${ }^{4}$ Wasisto Raharjo Jati, Cyberspace, Internet Dan Ruang Publik Baru : Aktivisme Online Politik Kelas Menengah Indonesia, Jurnal Pemikiran Sosiologi, Vol 3 No 1 (Januari 2016), 29

${ }^{5}$ Jeff Zaleski, Spiritualitas Cyberspace, Mizan, Bandung : (September 1999), 51
} 


\section{b. Keluarga}

\section{1) Definisi Keluarga}

Menurut departmen kesehatan RI keluarga adalah unit terlecil dari masyarakat yang terdiri atas kepala keluarga dan beberapa orang yang berkumpul dan tinggal disuatu tempat dibawah suatu atap dalam keadaan saling ketergantungan.

Menurit salvicion G Bailon dan Aracales maglaya keluarga adalah dua atau lebih dari dua individu yang tergabung karna hubungan darah, hubungan perkawinan atau pengangkatan dan mereka hidup dalam suatu rumah tangga, berinteraski satu sama lain, dan didalamnya peran masingmasing menciptakan serta mempertahankan kebudayaan ${ }^{6}$.

Keluarga dalam Al-Qur'an memiliki term-term (istilah-istilah) tersendiri dalam penyebutannya salah satunya ahl dimana ahl memiliki dua akart kata yang berbeda jauh pengertiannya pertama ahl artinya lemak yang diiris dan di potong kecil-kecil dan yang kedua kata ahl itu sendiri yang baru di pahami pengertiannya setelah di ranglai dengan kata lain sehingga membentuk suatu kata majemuk. Sehingga kata ahl dalam alqur'an menjadi ahlun yang berbentuk jamak. Menurut Al-Asfahani ada dua macam ahl dalam al-qur'an pertama yang bersifat sempit atau yang disebut ahl-ar-rajul yaitu keluarga yang senasab, seketurunan atau berhubungan darah, mereka dapat berkumpul dalam tempat tinggal7. Ahl dalam pengertian ini terdapat dalam surat al-ahzab: 33, didalam ayat tersebut dijelaskan oleh ulama tafsir ditunjukan kepada keluarga nabi muhammad saw, yang disebut al-bait pada ayat ini yaitu istri dan putri nabi, jadi bisa di ambil kesimpulan bahwa definisi keluarga dalam arti sempit yaitu kumpulan laki-laki dan perempuan yang di ikat oleh tali pernikahan dan didalamnya terdapat orang yang menjadi tanggungan. Karna sekurangkurangnya keluarga yaitu terdiri dari suami,istri dan anak serta di ikat tali

\footnotetext{
${ }^{6}$ Nasrul Effendy, Dasar-Dasar Keperawatan Kesehatan Masyarakat. ( Jakarta: Buku Kedokteran EGC, 1998), 34

${ }^{7}$ Ahmad Badrut Tamaman, Keluarga Dalam Perspektif Al-Qur'an; Sebuah Kajian Tematik Tentang Konsep Keluarga, Kurnal Komunikasi Dan Penyiaran Islam, Vol 2 No 1 (Juni 2018), 2
} 
pernikahan ${ }^{8}$. Definisi ahl dalam arti luas menurut Al-Asfahanani yaitu keluarga seagama yang terdapat dalam surat hud: 46.

Dari beberapa definisi yang ada dapat tarik benang merah bahwa keluarga adalah unit terkecil dalam masyarakat, terdiri dari dua orang atau lebih, ada ikatan perkawinan dan pertalian darah, hidup dalam satu rumah tangga, di bawah asuhan kepala keluarga,berinteraksi di natara sesama anggota keluarga, setiap anggota keluarga memiliki peran masing-masing.

\section{2) Fungsi Keluarga}

Keluarga yang terdiri dari unsur ayah, ibu, anak memiliki peran masing-masing dalam nya antara lain ayah merupakan suami dari istri dan anak-anak yang berperan sebagai pencari nafkah, pendidikan, perlindungan, dan pemberi rasa aman, sebagai kepala keluarga, sebagai anggota kelompok sosial dalam lingkungan masyarakat. Ibu sebagai istri dan ibu dari anak-ananya memiliki peran untuk mengurus rumah tangga, sebagai pengasuh dan pendidik anak-anaknya, pelindung dan sebagai salah satu anggota sosial dalam lingkungan masyarakat, bukan hanya itu ibu juga dapat berperan sebagai pencari nafkah tambahan di luar rumah. Anak berperan melaksanakan peran psiko sosial sesuai dengan tingkat perkembangan baik fisik, mental dan spiritual.

Bukan hanya itu saat masing-masing anggota keluarga telah mengetahui peran-peran dalam keluarga, maka pola keluarga harus dijalankan berdasarkan fungsi keluarga yang ada agar terciptanya keluarga bahagia sejahtra. adanya sebuah keluarga adalah untuk menjalankan fungsi, dan fungsi yang keluarga yang dimaksud antara lain :

a) Fungsi agama, tugas anggota keluarga adalah untuk memperkenalkan dan mengajak anak dan anggota keluarga yang lain untuk hidup beragama, menanamkan nilai agama agar terciptanya generasi yang religius dan patuh terhadap aturan agama.

b) Fungsi pendidikan, dalam hal ini tugas keluarga adlaah medidik dan menyekolahkan anaknya untuk mempersiapkan kehidupan dimasa

${ }^{8}$ Amrullah Syarbini, Model Pendidikan Karakter Dalam Keluarga (Revitalisasi Peran Keluarga Dalam Membentuk Karakter Anak Menurut Perspektif Islam), (Jakarta: PT Alex Media Komputindo, 2014 ), 22 
depan. Agar anak memiliki bekal untuk menghadapi perkembangan zaman.

c) Fungsi sosial, tugas keluarga adalah untuk mengajarkan dan mempersiapkan anak menjadi anggota masyarakat yang dapat menjunjung tinggi norma-norma sosial sehingga tercipta generasi yang sanun.

d) Fungsi perlindungan, tugas keluarga dalam hal ini adalah untuk melindungi anak dari tindakan-tindakan yang tidak baik sehingga anggota keluarga merasa terlindungi dan merasa aman.

e) Fungsi perasaan, dalam hal ini keluarga bertugas untuk menjaga Secara instuitif perasaan dan suasana anak dan anggota lainnya dalam berkomunikasi sehingga tumbuh rasa saling mengerti yang akhirnya tercipta keharmonisan dalam keluarga

f) Fungsi rekreatif, keluarga dalam hal ini berfungsi untuk saling menghibur, menciptakan susasana menyenangkan, agar anggota keluarga menjadikan keberadaan keluarga sebagai penetralisir kepenatan saat beraktifitas.

g) Fungsi ekonomi, tugas kepala keluarga dalam hal ini mencari sumber-sumber kehidupan dalam memenuhi fungsi-fungsi yang lain, kepala keluarga bekerja memperoleh penghasilan, mengatur penghasilan sedemikian rupa demi memenuhi kebutuhan hidup anggota keluarga.

h) Fungsi biologis, dimana tugas ini adalah untuk meneruskan keturunan untuk keberlangsungan hidup generasi yang akan datang. ${ }^{9}$

Ketika membicarakan masalah fungis maka erat kaitannya dengan konteks kegunaan. Dimana ketika sebuah keluarga telah menerapkan ke 8 fungsi keluarga tersebut dengan efektif, maka akan menghadirkan generasi penerus yang berkualitas dan berdaya saing untuk kemajuan masyarakat, dari segi agama, pendidikan, sosial, ekonomi, intuisi, perlindungan, rekrasi dan biologis.

\footnotetext{
${ }^{9}$ Nasrul Effendy, Dasar-Dasar Keperawatan Kesehatan Masyarakat, 36
} 


\section{3) Konsep Keluarga Ideal}

Konsep keluarga idela pastinya di awali dengan sebuah ikatan pernikahan atau perkawinan yang sah dan di akui, dimana dalam membentuk keluarga yang sah harus sesuai syarat yang berlaku baik dari agama maupun dari hukum negara.

Menurut bag M. Leter menyatakan bahwa perkawinan adalah sebuah ikatan lahir batin antara seorang oria dan seorang wanita sebagai suami istri yang bertujuan untuk membentuk keluarga yang bahagia dan kekal berdasarkan kaidah ketuhanan yang maha esa. Islam menjelaskan bahwa perkawinan adalah perjanjian aqad atau kontrak yang mana perjanjian hanya dapat di capai oleh dua orang pihak yang sudah saling mengenal dan perjanjian yang sudah di ikat tidak mudah untuk di batalkan maka dari itu sebelum menentukan perjanjian terlebih dahulu calon suami istri untuk saling mengenal agar dapat saling memahami tabiat masingmasing.

Keluarga merupakan kelompok kecil yang memiliki struktur pemimpin dan anggota dan mempunyai pembagian tugas dan kerja serta memiliki hak dan kewajiban bagi masing-masing anggota keluarga. Dimana keluarga adalah tempat utama untuk anak-anak belajar dan dari keluarga pula mereka mempelajari sifat-keyakinan, sifat mulia komunikasi dan interaski sosial dan keterampilan hidup. Bentuk konsep keluarga ideal adalah memenuhi syarat-syarat sebagai berikut :

a) Sebuah keluarga dikatakan keluarga saat sudah di ikat oleh tali pernikahan

b) Pernikahan sesuai hukum agama dan negara

c) Menikah dengan pasangan yang satu keyakinan

d) Memiliki unsur keluarga yang lengkap (ayah, ibu, anak)

e) Mendapatkan keturunan

f) Pasangan suami istri harus saling mengenal

g) Pasangan hidup hendaknya saling menyayangi agar tercipta ikatan batin

h) Setiap anggota keluarga saling menciptakan dan merasakan hidup tentram 
i) Setiap anggota keluarga memiliki hak dan kewajiban

j) Saling menghormati antara hak dan kewajiban anggota keluarga yang lain

k) Membuat tugas masing-masing anggota keluarga sesuai porsinya

l) Memiliki waktu yang cukup untuk berkumpul keluarga dan memiliki komunikasi yang efektif ${ }^{10}$.

Indikator terbentuknya keluarga ideal sudah di jelaskna secara umum berdasarkan syarat-syarat di atas, dimana keluarga ideal yang paling penting adalah yang terbentuk atas dasar agama yang sama kerna jika bernagkat dari fungsi keluarga, ada fungsi yang menjelaskan tentang fungsi agama dimana agama merupakan pondasi dan alasan seorang insan untuk melangsungkan sebuah ikatan pernikahan salah satunya yaitu sebagai bentuk ibadah. Terlepas dari itu keluarga ideal merupakan sebuah gambaran keluarga yang sempurna dimana masing-masing keluarga memiliki indikator dan karakteristik masing-masing dari sebuah keluarga ideal, namun secara umum sebuah keluarga dibentuk adalah untuk beribadah, memiliki keturunan, dan menciptakan rasa cinta kasih sehingga keluarga menjadi tentram, bahagia, sejahtra.

\section{c. Komunikasi Interpersonal}

Komunikasi interpersonal merupakan bentuk komunikasi yang sering di lakukan sehari-hari dimana ada interaski antara komunikan dan komunikator, menurut trenholm dan jensen mendefinisakn komunikasi interpersonal sebagai komunikasi antara dua orang yang berlangsung secara tatap muka .

Menurut littlejohn definisi komunikasi interpesonal adalah komunikasi antarpribadi (lintas personal comunication) atau komunikasi antar individu. Agus M hardjana mengatakan komunikasi interpersonal adalah interaksi tatap muka antara dua atau beberapa orang. Dimana pengirim dapat menyampaikan pesan secara langsung dan penerima dapat menerima dan menanggapi secara langsung pula, dan pendapat tersebut senada dengan deddy mulyana bahwa komunikasi interpersonal atau komunikasi antarpribadi adalah komunikasi

${ }^{10}$ Helmawati, Pendidikan Keluarga teori dan praktis, (Bandung: Rosda, 2014), 42-43 
antara orang-orang secara tatap muka, yang memungkinkan setiap pesertanya menangkap reaksi secara langsung, baik secara verbal maupun non berbal ${ }^{11}$. Komunikasi interpesonal memiliki ciri-ciri khusus antara lain.

1. Arus pesan dua arah, dimana komunikasi interpersonal menempatkan sumber pesan dan penerima pesan sejajar.

2. Suasana nonformal, komunikasi interpersonal biasnaya terjadi spontan dimana saja dan kapanpun yang bersifat nonformal

3. Umpan balik segera, dimana proses komunikasi langsung saling memberi tanggapan antara komunikator dan komunikan

4. Peserta komunikasi berada dalam jarak yang dekat, komunikasi interpersonal merupakan komunikasi natar individu yang menuntut berada dalam jarak yang dekat.

5. Peserta komunikasi mengirim dan menerima pesan secara simultan dan spontan, baik secara verbal maupun secara nonverbal, untuk meningkatkan efektivitas komunikasi. ${ }^{12}$

Komunikasi interpersonal merupakan suatu aksi yang memiliki orientasi pada tujuan tertentu, tujuan komunikasi interpersonal itu beragama antara lain :

1. Mengungkapkan perhatian kepada orang lain

2. Menemukan diri sendiri

3. Menemukan dunia luar

4. Memelihara dan membangun hubungan yang harmonis

5. Mempengaruhi sikap dan tingkah laku

6. Mencari kesenangan atau sekedar menghabiskan waktu

7. Menghilangkan kerugian akibat salah komunikasi

8. Memberikan bantuan (konseling) ${ }^{13}$

Komunikasi interpersonal merupakan tindakan statis tetapi berkembang, dimana komunikasi interpersonal merupakan proses komunikasi yang berkembang, berbeda-beda tujuaan tergantung dari tingkat hubungan pihak-pihak yang terlibat didalamnya, dalam prosesnya komuniaksi

\footnotetext{
${ }^{11}$ Suranto Aw, Komunikasi Interpersonal, (Yogyakarta: Graha Ilmu, 2011), 3

12 Ibid, 15

13 Ibid, 19
} 
interpersonal merupakan jenis komunikasi yang efektif dalam upaya persuasif, mengubah sikap, pendapat, atau prilaku seseorang.

Untuk mencapai tujuan dari komunikasi yang di lakukan, maka diperlukan komunikasi yang baik agar komunikasi dapat berjalan efektif. Menurut devito karakteristik efektivitas komunikasi interpersonal ini apat dilihat dari tiga sudut pandang yaitu :

1. Sudut pandang humanistik

Sudut pandnag ini fokus kepada keterbukaan, empati, dan sikap mendukung, kaulitas-kualitas lain yang menciptakan interaski yang bermakna, jujur dan memuaskan. Dimana menurut para filsuf humanis adalah faktor penentu terciptanya hubungan antarmanusa yang superior

2. Sudut pandnag pragmatis

Sudut pandang ini menekankan pada manajemen dan kesegaran interaksi, secara umum kualitas komunikasi emnjadi penentu tercapainya tujuan komunikasi. Panddangan ini berawal dari keterampilan spesifik misalnya : kepercayaan diri, manajemen interaksi, pemantauan diri, daya ekspresi, orientasi kepada orang lain dan sikap positif)

3. Sudut pandang pergaulan sosial dan sudut pandang kesetaraan

Sudut panddang ini didasarkan pada model ekonomi imbalan biaya, sudut pandang ini mengasumsikan bahwa hubungan merupakan suatu kemitraan dimana imbalan dan biaya slaing dipersatukan

Adapun hal yang dapat dipahami dalam melakukan proses kounikasi interpersonal adalah berusahalah menyampaikan pesan atau informasi itu dengan landasan kejujuran dan keterbukaan, dan berikan waktu yang seluasluasnya kepada komunikan untuk menyampaikan pendapatnya, dan jangan sekali-sekali memotong pembicaraan seseorang yang belum selesai, fokus kepada lawan bicara dan jangan menunjukan sikap acuh serta tumbuhkan rasa saling percaya. Dengan begitu segala tujuan dari komunikasi interpersonal yang kita lakukan dapat tercapai dengan baik. ${ }^{14}$

14 Ida Suryani Wijaya, Komunikasi Interpersonal Dalam Organisasi, Jurnal Dakwah Tabligh, Vol 14 No 1 (Juni 2013), 119-120 


\section{Hasil Penelitian}

\section{a. Dampak Cyberspace Dalam Penerapan Fungsi Keluarga}

Berdasarkan penelitian yang di lakukan di kecamatan catur tunggal sleman yogyakarta ada 5 keluarga yang menjadi fokus penelitian penulis yaitu keluarga bapak AS (26 thn), RH (24 thn), AW ( 26 thn), SAH (28 thn) dan GA (24thn) dilihat dari usia nya para narasumber terbilang masih muda, dan lima keluarga ini adalah pengguna cyberspace dengan intensitas yang cukup sering sehingga terlihat dari pola asuhnya terhadap anak serta pola pembentukan keluarga tidak sesuai fungsi keluarga yang ada, ke lima keluarga tersebut cenderung moderta terhadap tujuan hidupnya. Gambaran singkat terkait pergeseran fungsi keluarga yang terjadi berdasarkan hasil penelitian penulis adalah sebagai berikut:

1) Fungsi agama. Selayaknya keluarga menjadi madrasah pertama penguatan agama terhadap anak akan tetapi di cyberspace pendidikan agama dalam keluarga tidak lagi menjadi prioritas dikarnakan kurnagnya kesadaran orang tua untuk mengajarkan anak-anaknya tentang pentingnya agama.

2) Fungsi ekonomi. Keluarga di era cyberspace sangat berorientasi dengan materi, terbukti tugas mencari nafkah tidak hanya di lakukan oleh ayah akan tetapi ibu ikut mencari nafkah. Hal ini terjadi karna peran media dan budaya populer yang membentuk pola seperti itu di masyarakat. Sehingga akan berdampak kepada anak yang merasa terasingi.

3) Fungsi pendidikan, ayah dan ibu adalah guru pertama untuk anak-anaknya, namun istilah tersebut sudah di ambil alih oleh kecangihan teknologi dimana anak-anak lebih memilih belajar menggunakan media virtual yang di fasilitasi oleh orang tuanya. Hal ini akan membentuk jarak antara anak dan orang tua karna salah satunya dalam proses belajar anaklah intuisi anak dan orang tua di satukan.

4) Fungsi intuitif, ikatan darah yang terjalin didalam angota keluarga menjadi salah alasan mutlak terjadinya sebuah hubungan, dan lebih dalam dari itu intuisi antara anggota keluarga cenderung lebih erat, dibandingkan dengan orang lain. Namun intuisi harus di bangun dengan kedekatan dan komunikasi antara anggota keluarga. Saat ini dengan hadirnya dunia baru didalam keluarga mengakibatkan tembok pemisah antara anggota 
keluarga, dimana komunikasi adalah sebuah kegiatan langka terjadi dimana hal ini di akibatkan oleh dunia virtual.

5) Fungsi sosial, hubungan sosial adalah sebuah kewajiban manusia yang terlahir di tengah masyarakat. Karna pada dasarnya manusia adalah mahkluk sosial yang selalu memiliki ketergantungan dengan orang lain. Di era cyberspace hubungan sosial sekaan menajadi hubungan yang tabu karna saat ini masing-masing individu sudah di didik individualis dalam keluarganya. Dengan segala ketersediaan fasilitas yang memadai anakanak lebih suka bermain dirumah dengan segala kesibukannya di dunia virtual, sehingga tercipta sikap individualis dan masa bodo terhadap keadaan sekitar.

6) Fungsi rekreatif, keluarga adalah tempat pulang, ketika seharian sibuk dengan rutinitas, kembali bersama keluarga sekedar bercanda adalah hal yang menyenangkan, akan tetapi saat ini ada hal yang lebih menyennagkan dibanding keluarga yaitu media sosial dan future hiburan yang ada di gadget. Seolah tidak ada interaksi semua anggota keluarga diam dan asyik dengan dunia nya sendiri. Itulah yang terjadi di era cyberspace

7) Fungsi perlindungan, dengan perkembangan dunia virual yang menyajikan banyak produk untuk kebebasan berexpresi maka sebuah fungsi perlindungan dalam keluarga akan di ambil oleh

8) Fungsi biologis, pada dasarnya terbentuknya sebuah keluarga adalah untuk melahirkan keturunan baru untuk keberlangsungan hidup dimasa yang akan datang, akan tetapi dengan kecanggihan teknologi untuk mendapatkan keturunan tidak harus menjalin ikatan perkawinan terlebih dahulu karna saat ini sudah banyak metode pembuahan di luar hubungan pernikahan. Hal ini akan merusak legalitas keluarga dalam hubungan masyarakat.

Pada dasarnya perkebangan dunia cyberspace akan memberikan dampak positif dan negatif dalam urusan masing-masing anggota keluarga, dampak positif yang diberikan dunia cyber untuk urusan pekerjaan ayah sangat banyak yaitu mempercepat proses kelola data untuk menunjang pekerjaan ayah, dan positifnya untuk ibu adalah dapat mempermudah urusan rumah tangga dengan alat bantu yang canggih dan edukasi untuk urusan 
rumah tangga, dan positifnya untuk anak adalah memudahkan anak dalam belajar.

Namun perkembangan dunia cyberspace juga memberikan dampak negatif yaitu manusia lebih mendewakan rasio atau akal, tujuan hidup manusia dipengaruhi pada pencapain materi ${ }^{15}$. Dan pengaruh negatif yang lain yaitu tampak dari gaya hidup yang ditandai dengan pola makanan, hiburan, mode, dan pemikiran hal ini di akibatkan doktrin media yang seakan mewajibkan penggunakanya untuk mengikuti tren yang ada. Tidak hanya itu hal tersebut juga mempengaruhi hubungan keluarga dimana sebuah keluarga lebih mementingkan dunia maya dibandingkan dunia nyata, ketika sebuah keluarga tidak lagi duduk bersama untuk canda gurau melainkan duduk bersama untuk menikmati sajian media di gadget nya masing-masing hal ini sangat memberikan pengaruh terhadapt generasi mendatang terutama anak-anak karna anak-anak saat ini sudah di latih untuk hidup indivialis dan tidak peka terhadap keadaan sekitar.

\section{b. Pendekatan Komunikasi Interpersonal Dalam Penerapan Fungsi Keluarga}

Era cyberspace memang sangat membantu dalam segala sektor kehidupan manusia saat ini, dalam bidang komunikasi jarak sudah bukan menjadi masalah lagi karna telah didukung perkembangan jaringan yang dapat mendekatkan hubungan dengan orang-orang yang lebih jauh missalnya melalui media sosial. Bukan hanya itu cyberspace menyajikan kemudahan lain nya yang bersifat hiburan, yaitu berupa visual maupun audio visual dan segala bentuk fasilitas multimedia sudah disajikan dalam wadah yang efisien yaitu gadged. Dari fakta-fakta yang dihipun peneliti sudah tidak diragukan lagi eksistensi cyberspace dalam kehidupan sehari-hari dimana gadget sudah menjadi kebutuhan primer untuk megakses dunia cyber. Ayah menggunakan gadget untuk melancarkan urusan pekerjaan, ibu menggunakan gaget untuk bersosial media, anak menggunakan gadget untuk hiburan (games), melihat fakta ini dapat di simpulkan intensitas manusia untuk saling berkomunikasi

15 Pangaribuan Lisbon, Kualitas Komunikasi Suami Istri Dalam Menjaga Keharmonisan Perkawinan, Jurnal Simbolika. Vol 2 No 2 ( Maret 2016) 
dengan orang lain sangat minim, jika dibandingkan intensitas manusia berinteraksi dengan dunia cyberspace.

Dari fakta tersebut perkembangan dunia cyberspace malah memberikan dampak buruk bagi sebuah proses komunikasi secara langsung dimana hubungan yang jauh semakin dekat dan yang dekat semakin jauh. Padahal dalam hubungan keluarga komunikasi bukan hanya sebagai sarana penyampai pesan dan informasi dari satu sumber ke sumber yang lain, akan tetapi komunikasi dalam keluarga juga dapat menjadi media untuk memenuhi kebutuhan fisik dan psikologis misalnya seorang anak bayi merasa lapar ia akan memberikan signal kepada orang tuanya dengan cara menangis maka komunikasi yang di lakukan bayi adalah untuk memenuhi kebutuhan fisiknya. Dan dalam keluarga juga pastinya banyak pesan yang ingin disampaikan oleh setiap anggota keluarga dari satu ke yang lain terutama pesan dari orang tua untuk anak, manfaat komunikasi ini tentu saja agar anak dapat menerima nasehat dari orang tua demi keselamatan anaknya didunia dan akhirat.

Secara singkat manfaat komunikasi dalam keluarga antara lain:

1) Dapat mengetahui apa yang ingin disampaikan oleh anggota keluarga

2) Dengan komunikasi yang baik dapat menghindari keluarga dari konflik

3) Komunikasi yang baik dapat memberikan keuntungan antar anggota keluarga baik fisik maupun psikis

4) Komunikasi dapat mempererat hubungan kekeluargaan

Dalam sebuah rumah tangga hubungan komunikasi antar anggota keluarga sebaiknya menggunakan komunikasi interpersonal dimana komunikasi ini sangat efektif dipraktekan dalam hubungan keluarga karna sifatnya yang nonformal jadi anggota keluarga bebas membicarakan apa sja terkait urusan pribadi maupun berdasarkan kepentingan bersama. konsep komunikasi interpersonal yang dapat di praktekan dalam keluarga untuk menjalankan fungsi keluarga antara lain :

1. Fungsi agama.dengan komunikasi interpersonal ayah dan ibu secara langsung memberikan pemahaman tentang agama, mengajarkan dan mampraktekan ibadah kepada anak dengan sabar sehingga anak akan merasa nyaman dan mudah memahami apa yang di smapaiakn orang tuanya 
2. Fungsi ekonomi. Tidak di hindari perkembangan teknologi saat ini kebutuhan keluarga semakin membengkak dan tak di hindari peran ibu juga sangat efektif dalam membantu perekonomian keluarga, akan tetapi harus memiliki prioritas dalam keluarga agar tidak ada yang jadi korban dari kepentingan ekonomi.

3. Fungsi pendidikan, ayah dan ibu adalah guru pertama untuk anakanaknya,dimana ayah dan ibulah orang pertama yang mengajarkan bicara, berdiri, berlari. semakin sering interaski antara orang tua dan anak dalam proses belajar akan semakin memeprerat hubungan antara anggota keluarga

4. Fungsi intuitif, komunikasi interpersonal bisa menjadi media penguat intuitif antara anggota keluarga. Ketika masing-masing anggota keluarga berbincang membicarakan kegiatan dan keluh kesahnya di lingkungan masyarakat maka insting masing-masing anggota keluarga akan tumbuh secara otomatis

5. Fungsi sosial, keluarga adalah sebagai gambaran sosial seseorang di lingkungan, ketika jiwa sosial sudah dibangun dalam keluarga menggunakan komunikasi yang efektif antar anggota keluarga maka peran sosial di masyarakat akan dapat berjalan dengan baik.

6. Fungsi rekreatif, keluarga adalah tempat pulang, ketika seharian sibuk dengan rutinitas, kembali bersama keluarga sekedar bercanda adalah hal yang menyenangkan, berbincang santai dengan ditemani teh dan kopi dapat membangun kebahagiaan tersendiriyang lahir dari rahim keluarga

7. Fungsi perlindungan, dengan komunikasi interpersonal dan saling keterbukaan antara masing-masing anggota keluarga akan melahirkan sikap protektif kepada aggota keluarga yang lain sehingga fungsi perlindungan dalam keluarga dapat terlaksana dengan baik

8. Fungsi biologis, ini adalah sebuah fungsi yang didsasari keyakinan antara suami dan istri terkait kelahiran generasi baru penerus bangsa

Berdasarkan penjelasan di atas inti utama terbentuknya sebuah keluarga yang bahagia sejahtra adalah dari hubungan komunikasi interpersonal yang efektif antara masing-masing anggota keluarga, karna 8 fungsi keluarga tidak dapat melahirkan sebuah tindakan yang nyata apabila 
dihalangi oleh proses komunikasi yang tidak berjalan dengan baik. Karna pada hakikatnya komunikasi pertama kali manusia di muka bumi adalah komunikasi bersama orang tuanya maka dengan memelihara komunikasi sama dengan memelihara keberlangsungan hidup suatu keluarga.

\section{KESIMPULAN}

Keluarga merupakan unit terkecil keberlangsungan hidup suatu masyarakat, msing-masing anggota masyarakat yang terdiri dari berbagai bentuk kepala keluarga memiliki kebutuhan sosial yang sama. Dimana kebutuhan tersebut akan berlangsung jika komunikasi masing-masing anggota masyarakat dapat berjalan dengan baik. Namun proses tersebut harus terlebih dahulu dipelihara dalam komunikasi antar anggota keluarga agar masing-masing anggota keluarga siap melaksanakan peran nya dalam hubungan masyarakat.

Ketika individu diserang sebuah perubahan signifikan dalam perkembangan teknologi hal tersebut harus di hadapi berdasarkan kebutuhan. Jangan sampai terlena dan melupakan tugas-tugasnya dalam kehidupan keluarga dan masyarkaat. Ketika perkembangan cyberspace digunakan untuk meningkatkan komunikasi dan silaturahmi hal tersebut jangan sampai mengorbankan komunikasi dengan orang terdekat.

Sebaik-baiknya komunikasi yang di lakukan dalam keluarga adah komunikasi interpersonal dimana komunikasi interpersonal memiliki peran penting dalam mengakrebkan antara anggota keluarga serta menjalin kedekatan batin dapat juga digunkana dengan komunikasi interpersonal. Perkembangan media cyberspace jangan dijadikan alasan untuk membangun jarak antara anggota keluarga akan tetapi dimanfaatka dengan baik agar komunikasi antara anggota keluarga semakin terjalin dengan baik 


\section{DAFTAR PUSTAKA}

Bajari Atwar, 2015, Metode Penelitian Komunikasi Prosedur,Tren, Dan Etika, Simbiosa Rekatama Media Bandung.

Effendy Nasrul, 1998, Dasar-Dasar Keperawatan Kesehatan Masyarakat. Buku Kedokteran EGC Jakarta.

Helmawati, 2014, Pendidikan Keluarga teori dan praktis, Rosda Bandung : September Ida Suryani Wijaya, 2013, Komunikasi Interpersonal Dalam Organisasi, Jurnal Dakwah Tabligh, Vol 14 No 1 (Juni)

Pangaribuan Lisbon, 2016, Kualitas Komunikasi Suami Istri Dalam Menjaga Keharmonisan Perkawinan, Jurnal Simbolika. Vol 2 No 2 (Maret)

Raharjo Wasisto Jati, 2016, Cyberspace, Internet Dan Ruang Publik Baru : Aktivisme Online Politik Kelas Menengah Indonesia, Jurnal Pemikiran Sosiologi, Vol 3 No 1 (Januari)

Sitompul Josua, 2012, Cyberspace, Cybercrime, Cyberlow, PT Tatanusa Jakarta.

Suranto Aw, 2011, Komunikasi Interpersonal, Graha Ilmu ,Yogyakarta.

Syarbini Amrullah, 2014, Model Pendidikan Karakter Dalam Keluarga (Revitalisasi

Peran Keluarga Dalam Membentuk Karakter Anak Menurut Perspektif Islam), PT Alex Media Komputindo Jakarta .

Tamaman Ahmad Badrut, 2018 S Keluarga Dalam Perspektif Al-Qur'an; Sebuah Kajian Tematik Tentang Konsep Keluarga, Kurnal Komunikasi Dan Penyiaran Islam, Vol 2 No 1 (Juni)

Zaleski jeff, 1999, Spiritualitas Cyberspace, Mizan, Bandung: September. 